\title{
Autonomous Learning Writing Promoted by the Use of Facebook Group
}

\author{
Khairil Razali \\ UIN ArRaniry Aceh \\ Jl. SyechAbdurra'ufKopelma Darussalam Banda Aceh \\ khairilrazali1976@gmail.com \\ Husnul Khatimah \\ UIN ArRaniry Aceh \\ Jl. SyechAbdurra'ufKopelma Darussalam Banda Aceh \\ husnulkhatimah.adnan@gmail.com
}

\begin{abstract}
In aglobalized world, internet facilities and social media are becoming increasingly important and take a strategic role in most of human activities. One of them is in the education and learning sector. This qualitative research explored the role of a Facebook group to increase students' autonomy in learning writing. The experiment was conducted with qualitative methodology to 6 students as a sample. The process of data collection is done through the media Facebook group which was developed during the data collection through observation and interviews. The research lasted for 30(thirty) days in which researchers became the administrator and facilitator. From the process of collecting and analyzing the data assumed that Facebook group influenced the autonomy and promote independent of students learning in writing.
\end{abstract}

Keywords: Facebook group, Students autonomy, Learning writing

\section{Abstrak}

Dalam dunia yang global, sarana internet dan media social menjadi semakin penting dan mengambil peran strategis dalam segala lini 
kehidupan manusia. Salah satunya adalah di sector pendidikan dan pembelajaran. Penelitian ini melakukan explorasi kualitatif tentang eran Facebook Group terhadap peningkatan kemandirian siswa dalam belajar writing. Penelitian dilaksanakan dengan pendekatan kualitatif terhadap 6 siswa sebagai sampel. Proses pengumpulan data dilakukan melalui media facebook group yang di desain untuk proses penelitian ini, observasi dan wawancara. Penelitian berlangsung selama 30 (tiga puluh) hari dimana peneliti menjadi pengelola akun dan fasilitator. Dari proses pengumpulan dan analisa disimpulkan bahwa media Facebook group mempromosikan dan mempengaruhi kemandiriaan siswa dalam kemandirian belajar writing.

Kata Kunci: Facebook group, Kemandirian belajar siswa, Belajar menulis

\section{Introduction}

Facebook is a global large social media that boosts more than 100 million followers, and it is one of the fastest-growing and best-known sites on internet these days. Initiated and established by Zuckerberg in 2004, Facebook as a network at first targeted high school and college students but it goes globally and actively gains its popularity of all people ages. (Blattner \& Fiori, 2009).

Literally, Hayashi (2011) has studied about the use of Facebook that contributed the increased students' motivation and language output. She explained that in Facebook students can enjoy written communication freely by sharing their ideas, via Facebook status or note. They also can comment to other's posting, and or share link, and video as well. However even so, she just tends to see the use of Facebook in general and focusing on the general language learning.

Learning writing in the classroom is not adequate to foster students' competence. Therefore, the demand of autonomous learning 
methods and techniques by learning outside classroom is increased. Autonomous learning as defined by Holec (cited in Hayashi, 2011) as "The ability to take charge of one's learning," had grown considerably in the field of language education. Lee (2011) stated that autonomous learning does not require learners to work in isolation; rather, they socially construct knowledge by actively engaging in the process of learning. Through social interaction, learners develop a capacity to receive information, and then to create a new perspective. It means, to lead students to get their autonomy in learning, the instructors must be able to create such community that appropriate for this need.

Fortunately, besides enhancing students' motivation to love writing, Facebook also provides an additional media to facilitate this need. One of the examples is Facebook group. 'Facebook group' is a feature that is available on the social networking site Facebook, where students are allowed to participate communicate and interact via post and chat for a specific purpose with unlimited number of people, and of course with unlimited usage of time.

This article mainly discusses the use of Facebook groups only. Actually, Yunus et al (n.d) has studied about the connection of Facebook group and learning writing. However, their focus is only on how Facebook develop students' preparation process in writing, which is brainstorming, before they are doing the real writing. Then, they looked at the issues from teacher point of view with having the result 'How to teach writing to ELS students by using Facebook group?'

Otherwise, this present study would explore more at how 'Facebook Group Promoting Students Autonomy in Writing Learning?' with the focus more on students point of view. According to Yunus et al 
(n.d) method, for this study, a Facebook group was created specifically for the purpose of providing students with a space where they were in control of the content and the direction of their learning, as well as providing more opportunities for students to write. The researcher merely acted as a facilitator for the group which apply scaffolding role, to give temporary support to help student move from lower stage to higher stage of development. Facebook group also allowed for almost immediate feedback and fun interaction that the researcher hoped will motivate students in improving their writing. The researcher hypothesized that Facebook group will benefit the students in motivating them to learn writing autonomously.

\section{Facebook}

Facebook has been a leading social media currently. Facebook has been gaining market share since launched in February 2004. It obtains over eight million users in the U.S. alone and expands worldwide to eight other English-Speaking Countries with more to follow (Yani, 2011). It started its corporation with high schools in the United States in September 2005 and followed crossing the Atlantic to universities in the UK (Yani, 2011). Now, the site becomes one of the biggest web sites in the world visited by 400 million people in a month.

In Indonesia, currently stands at the second largest Facebook market in the world. The fact, despite of its relatively slow internet connection compared to other countries, its rates grown rate from year to year that has been tremendously high. Bucher (as cited in Yani, 2011) reported the top 30 countries by number of active Facebook users with Facebook data from $1^{\text {st }}$ April 2011 compared to April 2009 and April 
2010, which is showed that Indonesia precisely the second stair after USA and above the UK. It is surprise when we recall back to the Facebook History development which showed that UK is the second home of Facebook in the beginning.

However, Sukmana (2011) states there are reasons statistically lead Indonesia at the second place of followers Facebook growth. Culturally,Indonesian is mostly based on sharing, communicating, and solidarity. Facebook facilitates Indonesian people to connect with their families, friends and collegues in their lives easily. As more and more people get connected through Facebook, people are not able to refuse to join it since most of their friends had been there. In addition, the fact mobile phone subscribers have reached more than 200 million in 2011 in Indonesia. It shows an increasingly trend. Another important reason is the demands and interests towards Facebook has led to innovative and impressive development of Facebook website, therefore, it leads to attracts users through its features and functions. Indeed, by the reason, exclusive network, photo-tagging, news feed, and great application including Facebook group resulted to a community-based cultural country like Indonesia promotes of the existence of Facebook and its group allowspeople to manage communication, moreover, it gives in some way Facebook increases its development in Indonesian Market rapidly.

Furthermore, Facebook has successfully won the heart of Indonesian people, moreover the young adults. Communication on Facebook group is mostly done in written type, therefore this study would like to find out how this popular media involves in developing 
students' autonomy in learning writing. To somehow the students' autonomy in learning is totally important in learning writing.

\section{Learner autonomy}

The origin theory and practice of autonomy in language learning emerged from Knowel'sresearch of self-directed learning (1975, cited in Kocak, 2003) which defined as a leading figure in adult education, as a process in which individuals accept responsibility for all the decisions concerned with their learning. In the 1970s and 1980s the focuses on adult self-directed learning was becoming popular.

Then, the term of autonomy firstly was introduced by Holec in 1981. It begins with the council of Europe's Modern Language project, which led to the publication of Holec's seminar report, in which autonomy is defined as 'The ability to take charge of one's own learning' (cited in Benson, 2006). However, the practical application focuses on self-directed learning and led the development of self-access centers and learner training as focal point for experimentation.

Therefore, as the more recent literature has begun to use the term 'self-directed learning' together with the concept of learning autonomy in the context of institutional education context, it treats autonomous learning as a synonym for self-directed learning. The only distinction between autonomy and self-directed learning is clearly emphasized by Dickinson (1987, cited in Kocak, 2003) who said that in selfdirectedlearning, learners accept responsibility for all decisions related to their learning but not necessarily implement those decisions; on the other hand, in autonomous learning the learners are entirely responsible for all 
the decisions concerned with their learning and also the implementation of these decisions.

Nevertheless, at that time, the issues of autonomous learning still involved around adult learning which is held out of the classroom-based. Then, in his book on learner training, Dickinson (1992, cited in Benson, 2003) argued that learner often acted 'independently,' both cognitively and behaviorally, in the classroom, while Dam (1995, cited in Benson 2003) demonstrated how principle of autonomy could be integrated into secondary school classroom without self-access or formal learner training. This then turn to the application of learner autonomy in the classroom context, which was as the second wave of the interest in learner autonomy in language learning and teaching.

Furthermore, Allwright (1988: 35, cited in Benson 2003) suggested for the re-conceptualizing autonomy if it was to be used to the classroom context. It is because, he defined autonomy as the long-life learning which was not being adequate captured by the classroom environment. This idea then was supported by the development of computer and internet usage for the academic educational purposes. This is third wave of the context for growing of the interest of autonomy in recent years. Indeed, the "tendency has been towards a blurring of the distinctions, leading to new and often complex understandings of the role of autonomy in language teaching and learning" (Benson, 2003).

Language skills can best be developed if the learner develops awareness of his or her own learning, and of the strategies and styles that are available. Strategic competence means being able to plan, implement, monitor and evaluate one's learning, and making use of all available opportunities both in and outside the classroom. 
Autonomy is often taken, mistakenly we believe, to be a solitary condition. However more and more writers are stressing the need for interaction and negotiation. Dam (1995, cited in Nordlund, n.d.) stressed the social dimension that "learner autonomy is characterized by a readiness to take charge of one's own learning in the service of one's needs and purposes. This entails a capacity and willingness to act independently and in co-operation with others, as a socially responsible person."

Therefore, in this learning, every participant is encouraged to response to each other writing, whether to appreciate it or to revise it. Their participation in commenting others would be well-observed.

An important part of language-learning awareness is the admission that a lot of learning goes on the outside the classroom. There has been considerable debate over whether autonomy is just another Western concept that is being forced on cultures that do not share the same values. However, there have been autonomous systems successfully applied and adopted in a wide range of cultures. This indicates that the problem may be more a misunderstanding about the deep values of different societies. Individual differences in learning styles, for instance, may be more important than learning strategies that have been acquired in a different classroom culture.

Furthermore, autonomous learning can be developed in almost any context and with any type of learner, but the context and culture have to be taken into account.

\section{Autonomous learning of writing}

Writing is a task, described by Levy and Olive as "one of the most complex activities that people can accomplish" (Dion, M. N., 
2011). It is undeniable that the hardest skill in English learning is writing which require learner's competency to receipt the information, process it, and at least, produce it. Seriously, learning writing is inadequate if only rely on the "two hours or four hours" learning in the classroom. Writing is about the long processes, which require more time, more effort, as well as more guidance.

Indeed, learners need to learn more outside the classroom in order to be a good writer, especially English writer. It is undeniably that the demand of autonomous learning in writing is such a crucial issue to be focused on. Therefore, in this study I would like to explore on how autonomous learning of writing could be developed by using Facebook Group Media, which is provided more space for the learning outside the classroom, but with the consideration that the learners still in touch with their social environment, as well as friends, teachers, or even English native speakers or writers.

As well as a complex subject, English writing has so large scope to be covered to, and therefore would be impossible conducting research on all aspect of it. Nevertheless, considering time limitation, participants' basic competence, I have to limit the writing scope into two authentic basic writing, that are; writing comment, and writing a paragraph.

In order to help the participants learn successfully, I provided the instructional process by using scaffolding approach, which was started from the lower level to the next. In this situation, I would start the learning process from the comment writing, and then paragraph writing. To guide the participants to gain better achievement, along with those writing instruction, I provided a slight explanation and basic links, and a 
rubric, so that they could monitor their learning, as well as their peer learning.

In recent years, interest in students' autonomy has grown considerably in the field of language education (e.g., Benson, 2003). Furthermore, along with the development of internet and its usage, there are also many studies that figured out about how is the internet usage can be adopted to the learning process, or facilitated the learning. Facebook as the most popular Social Networking Site (SNS) in the world now day also gained the attention of academic researchers, especially in the language learning issues.

Albertson (2011) studied the influence of Facebook to students' grammatical and pragmatic awareness; he did this study among Japanese learners of English that showed Facebook can lead students to be more aware about the grammatical and pragmatic used in daily communication. It is emphasized by $\mathrm{Wu} \mathrm{P}$. and Hsu L's study that deal with the connection of Facebook and EFL Learning (n.d). In their action research they got the result that Facebook improve students' language competence, as well as improving their motivation. Their research is in a line with Nowland's study which more focuses on students' motivation and autonomous learning. His result suggests the teacher to not only "teach a language, but to also inform and instruct how to study outside the classroom," and Facebook gladly provide it if the teacher understands to lead the students use it wisely. In addition, Blattner and Fiori (2009) conducted study more specific on Facebook usage in the classroom activities which was also resulting good conclusion on Facebook usage.

Obviously, if that circumstance was happening, the English learning process by using Facebook will become useless. As Wu P. and 
Hsu L. (n.d) concluded that the external factors, such as; "1) Audience, 2) quantity and quality of feedback from peers, 3) Topic preference, 4) Upcoming assignment and examination and 5) novelty effect," will become the disturbance of the learning process.

\section{Research design}

\section{Participants}

We conducted the research at the second grade students of Madrasah AliyahNegeri (MAN) Model Banda Aceh. The population of the research was 130 students. However, there was only 114 students participated in answering questionnaires.

Nevertheless, to get the detail of qualitative data, we limited the samples into six participants purposively; by giving them the questionnaires to select the appropriateness. The researchers distributed questionnaires to explore of how often they signed in Facebook, Facebook group, their writing passion, and their writing interest which is proved by how often they write a diary or anything a day.

\section{Data collection}

This study applied a descriptive qualitative approach. It explores understanding of a central phenomenon. There were three major procedures in collecting the data. They were observations, interviews and documents analysis. The research was carried on the Facebook group that the researchers created for this study purpose. Then research samples were added through their Facebook account into the group developed. To begin the conversation flow, the researchers started the conversation through simple and free topics started from free writing to introduce 
them. They research respondents were free to write anything they would like to such as their activities, and so on. To support the collection of the detail qualitative data, the learning activities were done merely in Facebook Group environment for 30 days. The observation activities were carried out on Facebook Group.

The learning process in the Facebook group was activated through "posting" as the instructional learning, and "comment" as the learning response to one another. To attract students, topics posted in the group were different from regular classroom learning process. It maintains more approaching to the basic learning of writing; which is more authentic and more needed as a base of their learning writing development, such as writing a good comment on the internet, and writing a good paragraph. Therefore, any of the participants' posting, both assignment and free posting, and comment in the Facebook Group were the document that would be analyzed for the research need.

\section{Discussion}

\section{The result of observation and document analysis}

The primary data for this research was the observation data from the Facebook group environment, which was more detail and comprehensive. Therefore, all of the participants' postings and comments in Facebook group were data of the research.

Actually, according to Thanasaulas's (2000), autonomous learning emphasized as the "path" of the learning process in which the learners go through, and it was not a product that can be produced, moreover in the very short period of time. It means, it is adequate hard to measure the autonomous learning. Therefore, in order to analyze and 
measure the participants' autonomous learning of English writing development during one month learning activities, we adopted Reinder's (2010) Eight-Stages of autonomous learning process as the patron for this measurement. Each of the stages highlights the learners in learning autonomously. The eight-stages were as cycle that could not be torn up each other. Those stages are; identifying needs, selecting goals, planning learning, selecting resources, selecting learning strategies, practice, monitoring the progress, and the last was assessment and revision.

Furthermore, in order to analyze those stages thoroughly, I will explain them separately;

1. Identifying needs

In this stage, before the learning was starting, the learners were asked to decide what they need to learn, and what condition they need in order to learn better. Therefore, we asked them to decide the rules of this group learning activities that need to be obeyed by all of the participants. In order to stimulate their opinion involvement; we suggested 3 rules to be applied; 1) be active and participate enthusiastically, 2) be respectful to each other by using well or polite language, and 3) be brave to talk and do not afraid of making mistake. However, those rules were opened to be eliminated or accepted, as well as the full opportunity for them to add other rules that theyneed. In this identifying needs stage, only two participants ( $\mathrm{C}$ and No) who decided what they need by adding other rules through their comments, but other participants (V, Na, I, and R) gave no responses.

- C: "I should add? no. 4. do not neglect the task given by admin. no.5 not active at night always, but when the sun is not setting too 
n often comment on and make suggestions. and that's all I can say. participation please!"

- No: "I agree with chohaekyungevilmagnae but, sorry maybe I can't active at night without the participation of its members will be difficult to realize that learning to our liking with"

2. Selecting goals

In this stage, the learners were asked to decide what the goals of our learning in this group are. They need to know and elaborate what they want to learn, in short, what kind of writing they want to master in through this learning media. Therefore, to help them think, we suggested them to learn about descriptive and/or narrative paragraph, but also with the same consideration that they might choose and decide their own. However, they had to elaborate why they need to learn and how.

3. Planning of learning

At this stage, there were no other participants were responding, the conclusion that other participants also agreed with those needs and goals that had been settled by $\mathrm{C}$ and No. Therefore, the learning process was started. It began with the writing comment learning. We posted a brief basic knowledge about how to write a good comment on the internet. Then, they explored their writing comment competency by commenting on other people's English posting, and reported them to the group, as well as their analysis of other comments in that posting. Then, every of them had to comment and revise each other report about writing comment.

Trying to understand the postings and the link given about comment, all of the participants have their own way in learning, as well as their strategy to plan their own learning. The participants wrote a 
reflection on the problem, the feeling toward the learning, etc. one of the participant reflected as follows;

"I like study about write comment, because I can know new vocabulary from other, but sometimes I can't understand all”

Nevertheless, in the next learning topic, learning about writing paragraph, almost all of the participants wrote their reflection about learning of writing paragraph.

In this reflection writing section, a participant, $\mathrm{V}$ reflected based on the reflection guideline, but she misunderstood the "planning learning" meaning in this context which was talking about the planning about how to learn the materials, but she talked about "the future plan." She explained about her future plans as " 2 . My plan after this I can learn to practice in daily life and I plan one more I want to learn to speak like a tourist, they understand my language and I can understand their language as well."

Fortunately, in this turn $\mathrm{C}$ understood the instruction well, but she wrote shorter reflection than the previous one. There are only several questions were covered in No's reflection, but it was very confusing answer about planning learning question; "lesson planning is done well, but to realize in need of sacrifice and hard work of both the recipient and the giver. Not all of the planning we can do well or according to plan lots of obstacles in this regard occurred."

\section{Selecting resources}

The learners selected their own learning sources. The participants were free to check and search any others as many as they wanted to. According to the explanation in stage 3, at this stage, there were only three participants $(\mathrm{C}, \mathrm{V}$, and No) explained their selecting resource 
process, while two others ( $\mathrm{Na}$ and I) were only talking about their feeling and one participant was giving no response. In this stage, $\mathrm{C}$ elaborated that she did not visit any other link because she felt that the link given was adequate for her learning as follows;

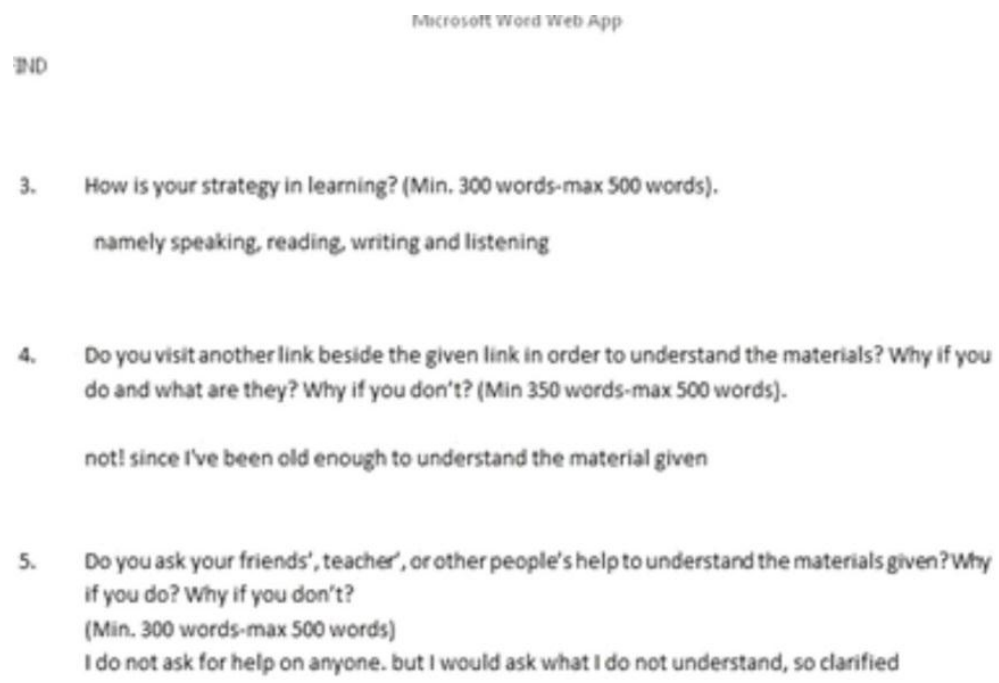

Otherwise, V said that she visit other link to help her understand what she read in the given link, as she said "I've also seen other people's links, if I am unsure of my mind, I saw it aims to correct my mistakes." however, unluckily, she did not mention the links she had visited to. This is in accordance with No's thought, which was visiting other links because she thought that learning something was not enough by visiting one link, as she said "of course because we can understand the learning of a variety of things not just one link only goal that we get more banyak pengetahuan." 
5. Selecting learning strategies.

The detail of those three participants' learning strategies were C elaborated in her first reflection that her learning strategies were by speaking, reading, writing, and listening, but in the second reflection she wrote that arranging time is her strategy in learning, as she said "to arrange a time to learn." Otherwise, V explained that her learning strategies was by trying to understand the materials giving by guessing and if she failed to guest, she would ask me directly, and she really did it, as she said "I am attempting guessing yourself what tasks the teacher, if I do not understand also recently asked directly at the teacher." The last is No, which was writing her learning strategies by trying to find the meaning of the material, and therefore she tried to look at the digital dictionary, AlFA link, and asking her friends, and very rare she asked me.

6. Practice

In this stage, the learners are asked to practice their learning by writing based on the task given. The task that was given had been designed based on the autonomous learning development consideration. Therefore, their participation in fulfilling the task by writing showed how their autonomous learning in writing developed.

To help them practice writing, in the beginning of the learning, I asked the participants to do free writing about themselves as the introduction. For this activity, all of the participants (C, V, Na, No, I, and $\mathrm{R})$ were participating very well. Indeed, before the learning was started, three participants (C, No, and V) had been starting writing by asking other participants' condition and/or just saying hello and good night, and $\mathrm{Na}$ also participated commenting on those posting. Furthermore, in the 
activity of "how to write a good comment" material posted the participants practiced writing comment by exploring comments of other people outside the group and posted its report in the group, even though those posting did not meet the deadline that had been settled together before. However, there are two participants ( $\mathrm{C}$ and $\mathrm{R})$ who were merely analyzing other people's comment, but they did not providing any comment in that posting.

7. Monitoring progress

The "monitoring progress" not only can be explored through the "seen check," it also can be seen from their opinion about the learning. Therewas one participant (C) who showed her opinion about the writing comment learning, as she said "oh come on guys .... please, further comments.. do not be quiet like this.. I'm bored -_-“

Interestingly $100 \%$ students participated at this stages, but with the detail that $69 \%$ of participant were highly participated observing others' posting, and only $15 \%$ who were critically giving opinion about the learning progress and 52\% were participating well, because they missed the last 5 posting and they did not give any opinion through the learning progress.

8. Assessment and revision.

In this last stage, the learners were asked to assess their peers learning as well as theirs. Therefore, their feedbacks for other participants were observed through their comments, but the feedbacks that assess others' posting will only be counted.

In this stage, the participants' participation decreased than previous stages. There were only three participants (C, V and R) who provided feedback to assess other participants' posting, but others were 
giving none. However, each of them only wrote one feedback in each learning step; C only wrote one feedback for writing comment learning in No's posting, but she did not provide any feedback for the writing paragraph learning. Otherwise, $\mathrm{V}$ and $\mathrm{R}$ did not provide any assessment feedback in writing comment learning, but they gave a feedback for their pair in the writing paragraph learning.

Furthermore, after assessment process (assessing others' posting and their own posting) the participants were asked to revise their posting according to the assessment. Nevertheless, for the revision process, only one participant (V) who did; she revised her paragraph, and others did none; even I and No whose paragraph was revised by the participants above.

\section{Data interpretation}

The result of Facebook group observation and document analysis shows that Facebook group media promotes students autonomous learning. The "practice" stages are considered as the main stages in writing learning, where all of the participants (100\%) fully engaged participating. All of the participants actively practice writing. In addition, all of the participants also showed full involvement in monitoring the progress. In addition, the interviews data exposed participants enjoy the learning process and the practice through media (Facebook Group).

Of six other stages, the participants showed different level of participation. Where for "selecting resources, selecting learning strategies", and assessment, there were only three participants showed the engagement, and for "planning learning, setting goals, and identifying needs" there were only two participants showed the involvement. 
Nevertheless, from the Facebook observation and document analysis, there is one participant (C) who was actively participated in the group, and fulfilled all of the eight stages of autonomous learning, but she did not realized that the Facebook group had promote her to learn writing autonomously. It can be seen from her interview answer that "the learning activity we had done in the group was not motivated me to love English writing." Otherwise, other participants' participation level is; V fulfilled 6 stages, No fulfilled 5 stages, R fulfilled 3, and the last $\mathrm{Na}$ and I fulfilled 2 stages.

In fact, the interviews data reflected the only factor of their problem in participating the learning in the group is the timing which students had timing conflict between participating in the research and completing the school assignments. Since "selecting goals, selecting learning, and assessment" had to be written in their reflection and it was done in the last time of the learning, it was approaching to their final examination timing and therefore they could not participate actively.

The participants stated that they love this type of learning which is more fun and relax. Even R and "I" that was fulfilling only two stages, they answered that they loved this kind of learning which was providing a lot advantages, especially for developing their English vocabulary, writing comment, and writing a paragraph. Indeed, "I" showed high enthusiasm of this learning and said that she wanted to be a member in other Facebook groups that provides English learning. Actually her answer and the participation in the group were contradictory, but then she explained that she got problem in accessing the internet connection. Therefore, it can be concluded that the Facebook group promote 
students' autonomy in learning writing, even though it was not significant.

\section{Conclusion}

This study concludes that the Facebook group promoted students' autonomy in learning English writing. It promotes students to practice writing more often, and also promotes students monitor the learning process. One of the reasons that the learners felt learning writing in the Facebook group as more fun and relax compared to routine classroom situation. However, for the selecting learning resources, selecting learning strategies, assessment, identifying needs, and setting goals the learners suffered from difficulty due to final examination and school assignments of students. Therefore, it is urgent to consider Facebook Group as a media in learning language mainly. The fact that it could promote autonomy; moreover, teacher should take consideration in a way to motivate students.

\section{References}

Albertson. 2011..Facebook Use and Pragmatic/Grammatical Awareness Among Japanese Learners of English. Department of English, Central Connecticut State University New Britain, Connecticut.

Benson, P. 2006. Autonomy in Language Teaching and Learning. State of The Art Article. United Kingdom; Cambridge University Press. Retrieved February 5 , 2013, fromhttp://www.google.com/url?sa=t\&rct=j\&q=book\%3B+autono mous+learnig $+\&$ source $=$ web $\& c d=10 \& c a d=$ rja $\& v e d=0 C G g Q F j A J$ \&url=http\%3A\%2F\%2Fwww4.pucsp.br\%2Finpla\%2Fbenson_artig o.pdf\&ei=HyJUUa_xCobIrQet0ICoAQ\&usg=AFQjCNHkLVbX1w rAUJCNrsJIm6KUTc3crw\&bvm=bv.44342787,d.bmk 
Blattner and Fiori. 2009. Facebook in the Language Classroom: Promises and Possibilities. International Journal Instructional Technology and Distance Learning.ISSN 1550-6908. P. 17-28. Retrieved March 6 , 2013 ,from https://www.google.com/url?sa=t\&rct=j\&q=\&esrc=s\&source=web $\& c d=1 \& c a d=$ rja\&ved=0CCwQFjAA\&url=http $\% 3 \mathrm{~A} \% 2 \mathrm{~F} \% 2 \mathrm{Flitu} . \mathrm{tu}$ .ac.th\%2Fkm\%2F05-

8\%2520Introduction\%2520to\%2520abstract $\% 2520$ Writing $\% 25201$ .pdf\&ei=ET2wUfz0BMyGrAeIvIHQAQ\&usg=AFQjCNHvYLM78 6D2gyFS_sv-zY7qckJEcw\&bvm=bv.47534661,d.bmk

Dion, M. C. 2011. Tools to Enhance Second Language Writing Autonomy: can we do things better? In Gardner, D. (Ed.), Fostering Autonomy in Language Learning (67-75).Gaziantep: Zirve University.

Hayashi, P. 2011. A Learning Success Story Using Facebook, SelfAccess learning Journal, 2 (4), Canada.

Kocak, Aifer. 2003. A Study on Learners' Readiness for Autonomous Learning of English as a Foreign Language. The Graduate School of Social Sciences of Middle East Technical University. Retrieved March 6, 2013

Lee, L. 2011. Blogging: Promoting Learner Autonomy and Intercultural Competence Through Study Abroad. Language Learning \&Technology, Volume 15, Number 3 pp. 87-109.

Nordlund, J. (n.d.). From Here to Autonomy: Autonomous Learning Modules (ALMS). Helsinki: Helsinki University Language Centre. Retrieved March 10, 2013, from http://www20.gencat.cat/docs/Llengcat/Documents/Publicacions/ Publicacions\%20en\%20linea/Arxius/VII_annex1.pdf

Reinders, H., \&Balcikanli, C. 2011. Learning to Foster Autonomy: The Role of Teacher Education Material. Studies inSelf-Access Learning Journal, 2 (1), 15-25.

Sukmana, J. March. 2007. Why Facebook is So Popular in Indonesia. Retrieved December, 9, 2013, from http://www.pennolson.com/2011/03/07/why-Facebook-is-so-popular-in-indonesial

Thanasoulas, D. 2000. What is learner Autonomy and How Can It be Fostered? The Internet TESL Journal, Vol. VI, No. 11. Retrieved March 8, 2013, from http://iteslj.org/Articles/ThanasoulasAutonomy.html

Yunus, et al (n.d), Using Facebook Group in Teaching ESL Writing, ISBN: 978-1-61804-060-2. Retrieved March 6, 2013, from 
https://www.google.com/url? sa=t\&rct=j\&q=\&esrc=s\&source=we $\mathrm{b} \& \mathrm{~cd}=2 \& \mathrm{cad}=\mathrm{rja} \& \mathrm{ved}=0 \mathrm{CDEQFj} \mathrm{AB} \& \mathrm{url}=\mathrm{http} \% 3 \mathrm{~A} \% 2 \mathrm{~F} \% 2 \mathrm{Fw}$ ww.wseas.us $\% 2 \mathrm{Fe}-$

library\%2Fconferences\%2F2011\%2FMontreux\%2FCOMICICBI O\%2FCOMICICBIO-

11.pdf\&ei=2kewUeSNIcuGrAesqYHQCw\&usg=AFQjCNEeJQY lxbNp5oCsQanrNnTcjtYtTQ\&bvm=bv.47534661,d.bmk

Yani, Muhammad. 2011. The Most Common Grammar Mistakes Made By English Students When Updating Facebook Status (a Study Case of English Students of Tarbiyah Faculty, IAIN ArRaniry.Tarbiyah Faculty IAIN Ar-Raniry Darussalam-Banda Aceh.

Wu, P., \& Hsu, L. (n.d.). EFL Learning on Social Networking Site?: An action Research on Facebook. Retrieved March 6, 2013, from

http://www.google.com/url?sa=t\&rct=j\&q=efl\%20learning $\% 20$ on $\% 20$ social $\% 20$ networking $\% 20$ site $\% 3 \mathrm{~F} \% 3 \mathrm{~A} \% 20$ an $\% 20$ actio n\%20research\%20on $\% 20$ Facebook\&source $=$ web $\& \mathrm{~cd}=1 \& \mathrm{cad}=$ rja\&sqi $=2 \& v e d=0 \mathrm{CC} 4 \mathrm{QFjAA} \& u r l=\mathrm{http} \% 3 \mathrm{~A} \% 2 \mathrm{~F} \% 2 \mathrm{Ftlvconf} . \mathrm{f}$ iles.wordpress.com\%2F2011\%2F04\%2Ftlv-paperwu.pdf\&ei=DGdRUeWgIoaKrgeOxYEw\&usg=AFQjCNEbiA TaCVv8WYCzp19nwsRJ2570ag\&bvm=bv.44342787,d.bmk 
